\title{
ON THE BIOLOGY OF CRANGON ALLMANI KINAHAN IN NORTHUMBERLAND WATERS
}

\author{
By J. A. Allen \\ Dove Marine Laboratory, Cullercoats \\ (Text-figs. I-I 5)
}

Since November 1954, the natant epifauna in depths greater than $20 \mathrm{fm}$. off the Northumberland coast has been sampled at a number of stations with the object of obtaining information on its constitution and fluctuations. The survey has been limited to those species caught with a net of $\frac{3}{4}$ in. mesh. Seasonal and yearly fluctuations in this fauna must have a considerable effect on the inshore fisheries, for these animals form an important part of the food of marketable fish, yet, this fauna has never been subject to a detailed analysis over a number of years.

Samples have been taken as regularly as weather and other laboratory commitments have allowed. In practice this has been of the order of one sample each month, but at times sampling has been more frequent than this (Table 8). Although sampling is being continued, the material collected so far gives much information on the epifauna as a whole and the biology of the constituent natant Crustacea and Mollusca.

It was soon clear that the best method for dealing with the samples was to analyse the biology of each of the commoner species in turn before reviewing the data as a whole. Pandalus borealis was the first species to be so considered (Allen, 1959). The second choice is Crangon allmani Kinahan ${ }^{\star}$. C. allmani has been chosen for the following reasons: (I) it is one of the more common offshore species of natant decapod in Northumberland waters; (2) in contrast to Pandalus borealis (Allen, I959) it occurs throughout the area below Io fm.; (3) it forms an important item of food for many marketable fish including the Whiting (Todd, I907; Jones, I954); Haddock (Ritchie, I937; Jones, I954); Thornback Ray and Long Rough Dab (Todd, I907) and others; and (4) virtually nothing is known of its biology.

While earlier authors doubt whether Crangon allmani is more than a subspecies of $C$. vulgaris (Doflein, 1900; Ortmann, I89I) observations by Wollebaek (I908) on the adult and by Sars (I890) and Lebour (I93I) on the larvae show that it is a distinct species. This study gives further emphasis to the differences between the two species and presents an opportunity to correct

* Kinahan (1857) named this shrimp Crangon allmanni. This is clearly a lapsus calami and the specific name should be spelt allmani. 
the original descriptions of Kinahan $(1857,186 \mathrm{I})$ and to figure the external anatomy more fully than hitherto.

I wish to thank Mr R. Harrison and the crew of the research vessel 'Alexander Meek' for collecting in all weathers. I am also grateful to $\mathrm{Dr} \mathrm{H}$. O. Bull for the use of his hydrographic data and for the helpful discussions during the course of the work, and to Dr R. B. Pike for information on the Clyde populations.
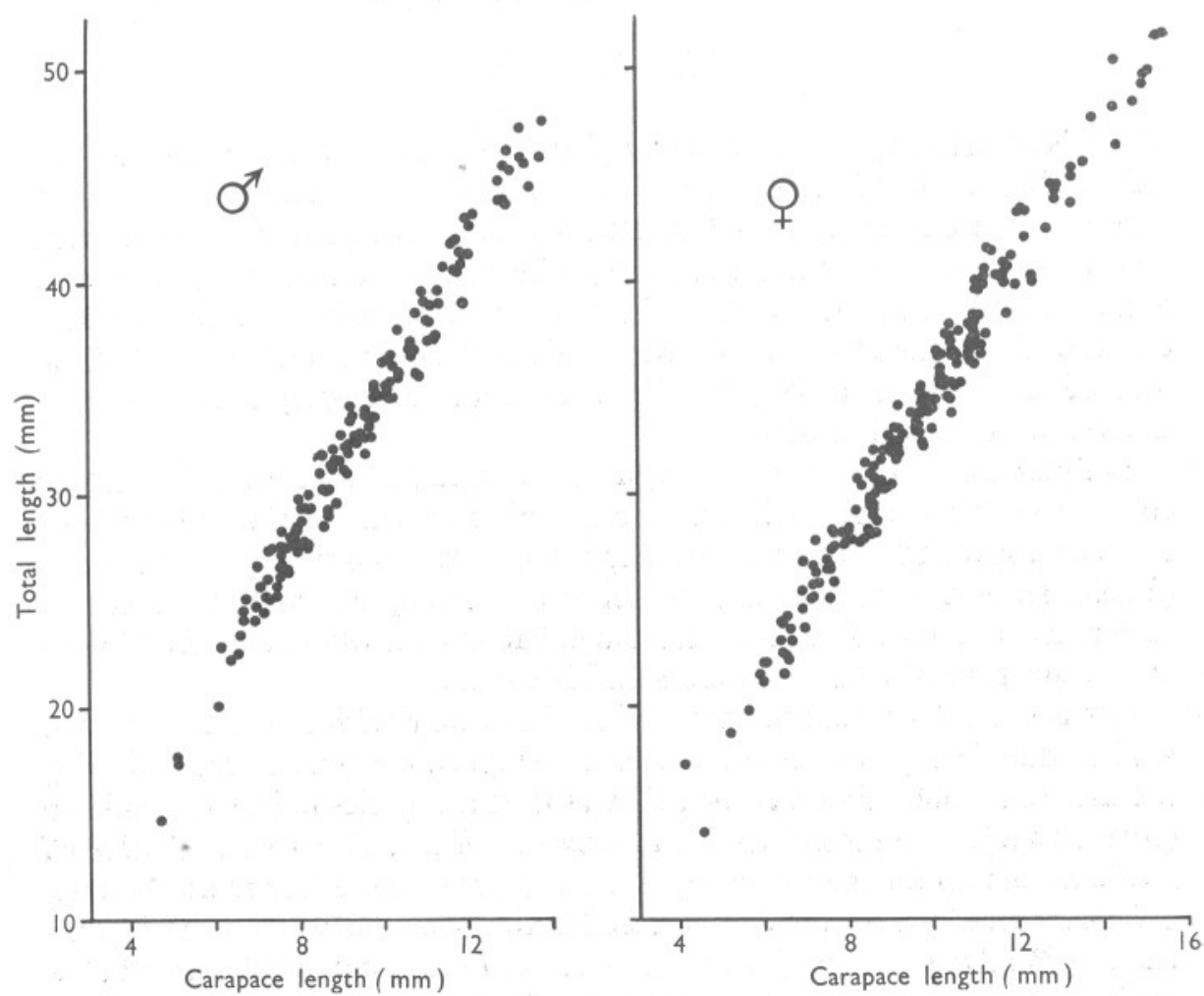

Fig. I. Relationship between carapace length and total length in male and female Crangon allmani.

\section{MATERIAL AND METHODS}

Throughout this work a $9 \mathrm{ft}$. trawl has been used. Until March 1956 a beam Trawl was used, but since that date an Agassiz trawl has been preferred. Each haul was of 20 min duration. The catch was sorted and, apart from a few specimens retained for observations in the aquarium, narcotized in fresh water, fixed in $4 \%$ neutral formalin for approximately $\mathrm{I} 2 \mathrm{~h}$ and then transferred to $90 \%$ alcohol. 
Later, length measurements were taken, sex determined and when eggs were present these were classified under one of the following four groups: $a$, early blastoderm; $b$, late blastoderm and early segmentation of the body; $c$, eye visible but abdomen not free from the head; $d$, well-developed abdomen and little yolk present. Specimens with egg remains and the larvae recently released, those in breeding dress and recently moulted shrimps were all recorded. Approximately 5\% (over 400) of the total number of C. allmani caught were retained for further examination. These animals were representative of the size range, sex and maturity within each sample. Each animal of the subsample was remeasured, pleopods examined and usually drawn to scale, gut contents examined, and maximum ova length recorded. Eggs were classified, counted and measured. Drawings were made of the appendages and body of males and females of varying sizes. The ratio of carapace length (tip of the lateral carapace spine to the posterior limit of carapace, see Fig. I2) to total length (tip of the rostrum to the tip of the uropod setae) was calculated (average 3.49, limits 3.23-3.71). This relationship was found to be linear, there being no significant difference between males and females (Fig. I). It was found that the lateral spine of the carapace (Fig. I2) was a far more accessible anterior point of reference for measuring carapace length than the more usual posterior limit of the eye socket; only rarely was the spine found broken. Measurements were carried out with a vernier caliper and taken to the nearest $0 . \mathrm{I} \mathrm{mm}$.

\section{DISTRIBUTION}

C. allmani is restricted to the eastern boreal region of the Atlantic. According to the literature, it extends from the White Sea to the northern part of the Bay of Biscay. It has been recorded for Iceland, it is present throughout the North Sea and the Kattegat and is found off all the coasts of Great Britain. It is apparently least plentiful off the south coasts of England and Ireland. In Danish waters and occasionally elsewhere it occurs in as little as $5 \mathrm{fm}$. of water, but its normal range extends from to to $100 \mathrm{fm}$. Off the Northumberland coast $C$. allmani has been taken at all depths below $9 \mathrm{fm}$. on every type of bottom with the exception of rock. The density of the population at any particular point may vary enormously. The $\mathrm{Io} \mathrm{fm}$. contour line (see Fig. 2) is the approximate offshore limit of $C$. vulgaris and, at certain times mixed populations occur at this depth. There has never been the slightest difficulty in separating the two species; colour, body shape and the bicarinate dorsal side of the sixth abdominal segment of $C$. allmani being infallible diagnostic characters.

During this study three main stations, A and B (inshore) and C (offshore), were sampled (Fig. 2). Originally sampling started inshore (St. A) two miles due east of Blyth Harbour in $25 \mathrm{fm}$. Soon after, the offshore station (St. C) 
I3 miles due east of this harbour in $50 \mathrm{fm}$. was sampled. By the autumn of I955 hopper refuse had fouled the 2 miles station, even though this was a mile inshore of the dumping grounds. This colliery refuse virtually wiped out the fauna and the ground became impossible to trawl over, so that a second inshore station (St. B) was sampled $\mathrm{I} \cdot 9$ miles, $050^{\circ}$ from Newbiggin Church in $22 \mathrm{fm}$. Additional samples have been taken throughout the area indicated in Fig. 2, but unless otherwise stated the data presented are from samples collected at the three stations.

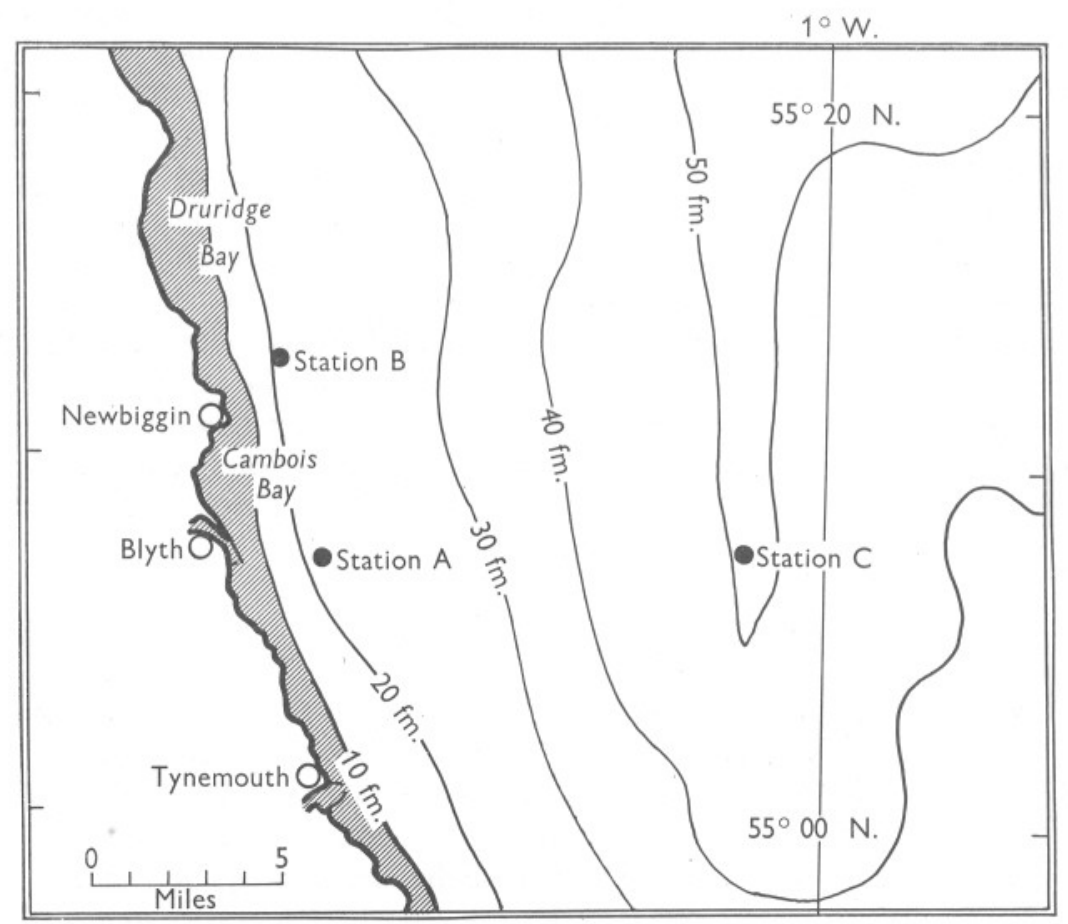

Fig. 2. The area investigated with the position of the Stations A, B, and C indicated. Crangon vulgaris is restricted to the hatched area and C. allmani to the non-hatched area.

Samples taken inshore during the first year showed a marked drop in the numbers of C. allmani caught during April and May (Fig. 3). This drop in numbers persisted throughout the summer and autumn months (May-October) and has proved to be a constant yearly occurrence at the inshore stations and elsewhere between 1o and $30 \mathrm{fm}$. Offshore C. allmani did not disappear during the summer months but it is clear that shrimps in $40-50 \mathrm{fm}$. are not evenly distributed and hauls without or with very few shrimps were taken throughout the year (Table 8). That the trawl was fishing on these occasions is indicated by the presence of normal numbers of other members of this 


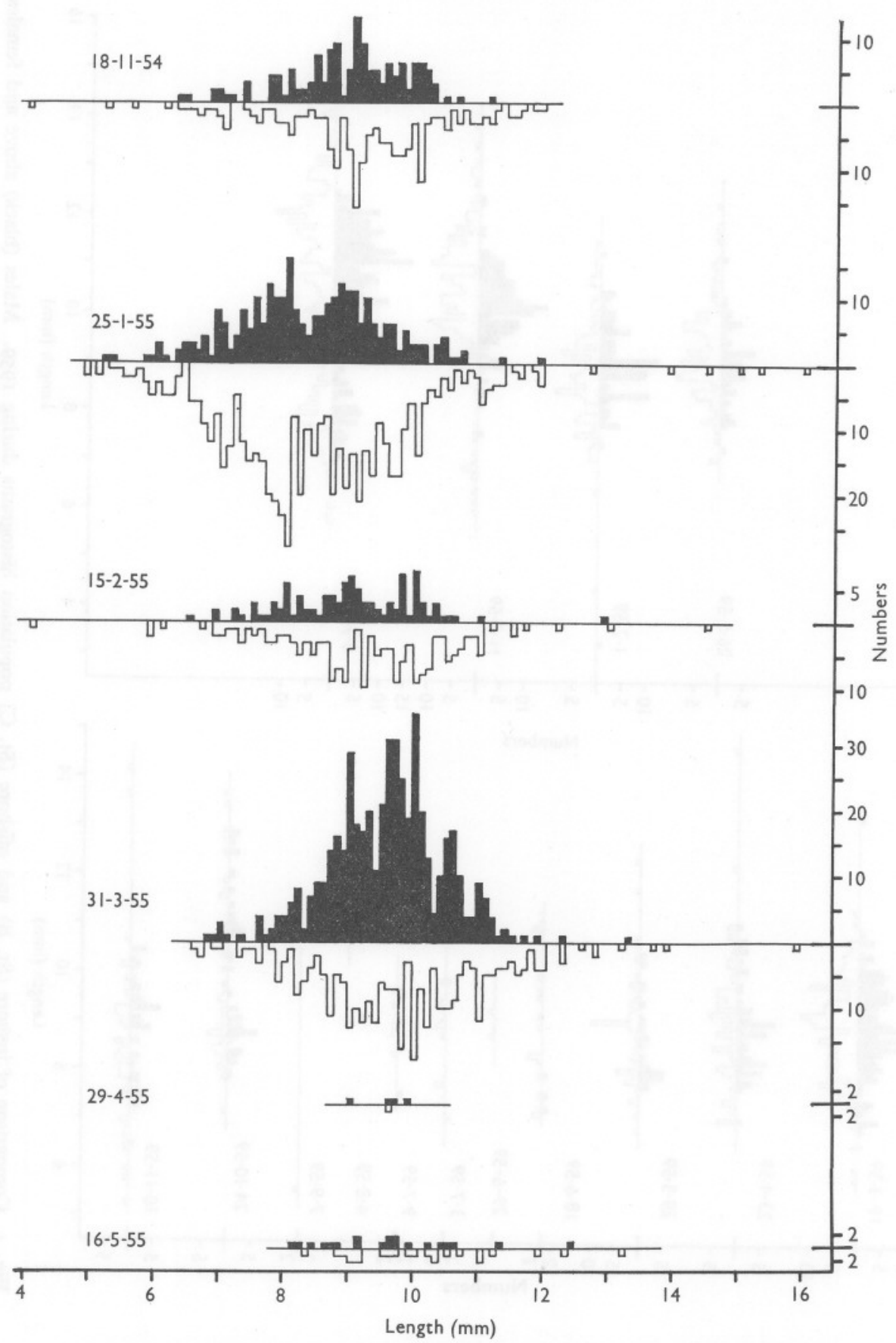

Fig. 3. Population histograms, in carapace-length groups, of the samples taken from Station A between November 1954 and May I955 Males (black) above and females (outlined) below the line. 

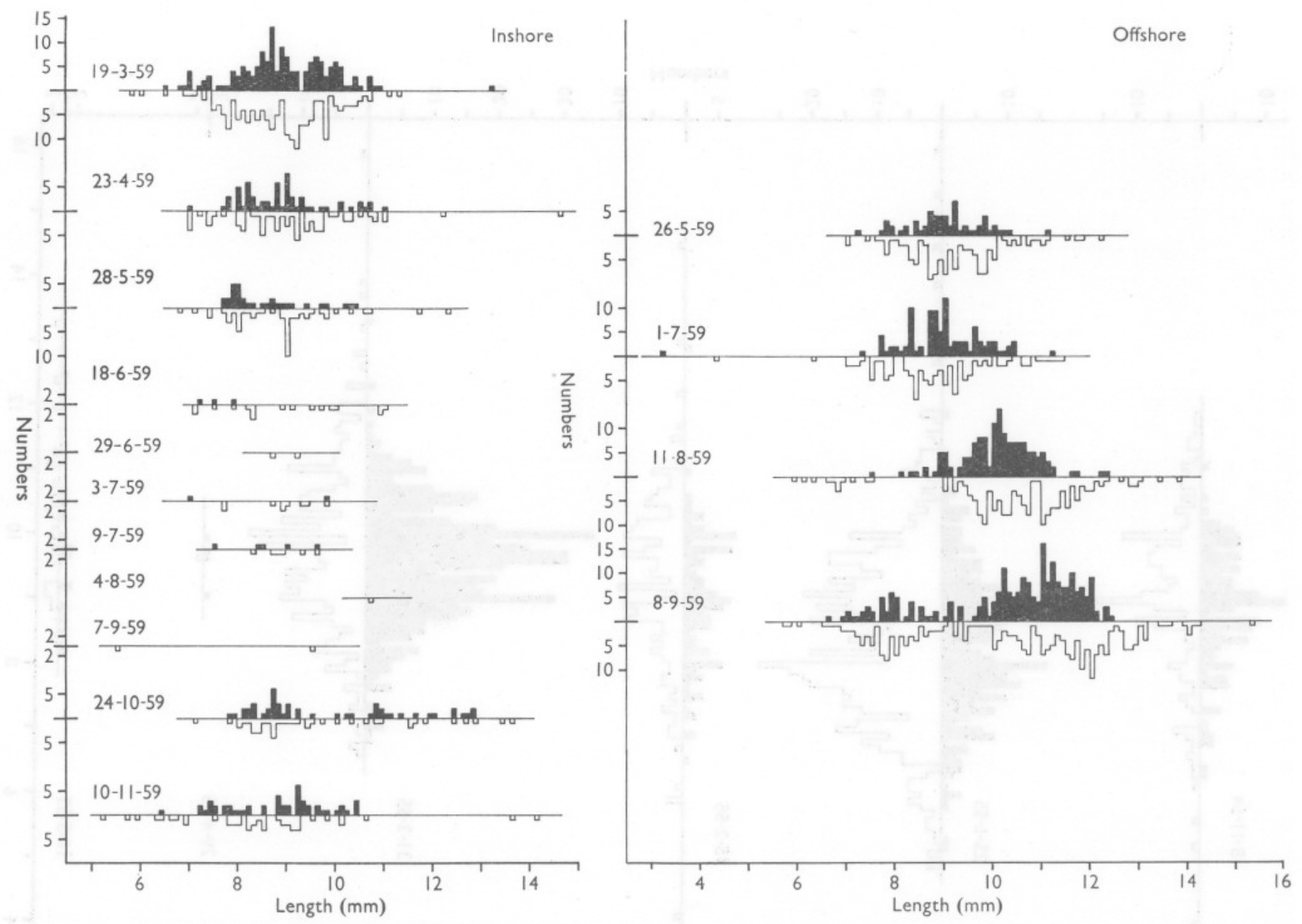

Fig. 4. Comparison of inshore (St. B) and offshore (St. C) population histograms during 1959. Males (black) above and females (outlined) below the line. The length given is that of the carapace. 
epifauna. This difference between inshore and offshore populations was closely observed in I959 (Fig. 4) when the trawling effort was increased in order to make sure that the inshore population had largely disappeared. Sampling outside the main stations indicates that this seasonal change can be observed in depths up to $35 \mathrm{fm}$. In this connexion it is of interest that examination of stomach contents of Whiting caught in the same area during I 953 to 1955 from depths of 20 to $30 \mathrm{fm}$. shows that while the fish are feeding predominantly on C. allmani during the months October to April few shrimps are present in the stomach contents from May to September (Goonewardene, unpublished $\left.{ }^{\star}\right)$. Although there is lack of direct evidence, there can be little doubt that the disappearance is the result of a migration. This will be assumed in the pages preceding the discussion of this point.

\section{BREEDING}

C. allmani is a dioecious species. Offshore, the average ratio of males to females was $0.98-I \cdot 00$ but with a wide range of $0.49-I \cdot I 2$ to $I \cdot 00$. Inshore, there are on the average far fewer males than females, the ratio being $0.62-$ $\mathrm{I} \cdot 00$, with the range being even wider than offshore $0 \cdot 15-\mathrm{I} \cdot 38$ to $\mathrm{I} \cdot 00$. This point will be further discussed when evidence for migration is presented (p. 503).

TABLE 1. AVERAGE MONTHLY PERCENTAGES OF THOSE FEMALE CRANGON ALLMANI IN BREEDING DRESS $(b d)$, THOSE BEARING EGGS AT STAGES $a-d$ AND THOSE WITH EGG REMAINS FOLLOWING THE RELEASE OF THE LARVAE $(l r)$

\begin{tabular}{|c|c|c|c|c|c|c|}
\hline & $b d$ & $a$ & $b$ & $c$ & $d$ & $l r$ \\
\hline Nov. & $\overline{60}$ & - & - & - & - & - \\
\hline $\begin{array}{l}\text { Dec. } \\
\text { Jan. }\end{array}$ & $\begin{array}{l}6.0 \\
0.8\end{array}$ & $\begin{array}{r}\mathrm{I} \cdot 5 \\
\mathrm{I} \cdot 8\end{array}$ & $\overline{6.0}$ & $\overline{0.0}$ & 二 & - \\
\hline $\begin{array}{l}\text { Jan. } \\
\text { Feb. }\end{array}$ & 0.5 & $\begin{array}{r}3.0 \\
4.6\end{array}$ & $\begin{array}{l}0.0 \\
4.9\end{array}$ & $\begin{array}{l}0.9 \\
0.7\end{array}$ & $\overrightarrow{\mathrm{I}} \cdot 8$ & E \\
\hline Mar. & $I \cdot 0$ & 12.4 & II 9 & $6 \cdot \mathrm{I}$ & $2 \cdot 8$ & $2 \cdot 7$ \\
\hline Apr. & - & 26.6 & $34 \cdot 7$ & 4.7 & - & 7.6 \\
\hline May & $I \cdot O$ & $26 \cdot 7$ & I3.9 & $9 \cdot 3$ & $2 \cdot I$ & II $\cdot 8$ \\
\hline June & - & 14.3 & $2 \mathrm{I} \cdot 4$ & $7 \cdot \mathrm{I}$ & $14 \cdot 3$ & $28 \cdot 6$ \\
\hline July & - & $31 \cdot 0$ & $\mathrm{I} \cdot 7$ & - & & 0.4 \\
\hline Aug. & 二 & - & - & - & - & 0.9 \\
\hline Sept. & - & - & - & - & - & \\
\hline
\end{tabular}

The percentages are calculated on total number of females per haul, i.e. no account is taken of immature females (see below).

Females bearing eggs first appear in small numbers ( $1.5 \%$ of all females $\dagger$ ) by the end of the first week in December. All the eggs are at stage $a$. By

* University of Durham, Ph.D. Thesis, 1956. 'The biology of the Whiting (Gadus merlangus Linn.).

† The percentages, unless otherwise stated, including those of Table $\mathrm{I}$ are based on the total number of females in the catch, i.e. including immature females less than $7.5 \mathrm{~mm}$ carapace length. The percentage of immature females is small (Table 2) and does not affect the results presented. 
TABLE 2. THE AVERAGE MONTHLY PERCENTAGE OF IMMATURE FEMALE CRANGON ALLMANI (LESS THAN 7.5 MM CARAPACE LENGTH) AND AVERAGE MONTHLY PERCENTAGE OF FEMALES GREATER THAN 7.5 MM CARAPACE LENGTH THAT ARE OVIGEROUS: INCLUDING THOSE IN BREEDING DRESS AND WITH EGG REMAINS AS WELL AS THOSE BEARING EGGS.

\begin{tabular}{|c|c|c|c|c|c|}
\hline & $\begin{array}{l}(\%) \\
\text { Immature } \\
\text { females }\end{array}$ & $\begin{array}{l}(\%) \\
\text { Ovigerous } \\
\text { females }\end{array}$ & & $\begin{array}{c}(\%) \\
\text { Immature } \\
\text { females }\end{array}$ & $\begin{array}{c}(\%) \\
\text { Ovigerous } \\
\text { females }\end{array}$ \\
\hline Dec. & I. 5 & $7 \cdot 6$ & June & I0.0* & $55^{\circ} 0^{\star}$ \\
\hline Jan. & $12 \cdot \mathrm{I}$ & $24 \cdot 2$ & July & $2 \cdot 9$ & $3 I \cdot 4$ \\
\hline Feb. & $6 \cdot 3$ & II $\cdot I$ & Aug. & $7 \cdot 2$ & $I \cdot 9$ \\
\hline Mar. & $4 \cdot 2$ & $3 \mathrm{I} \cdot 9$ & Sept. & $8 \cdot 6$ & - \\
\hline Apr. & $6 \cdot I$ & 55.9 & Oct. & $7 \cdot 4$ & - \\
\hline May & 2.9 & $49 \cdot \mathrm{I}$ & Nov. & $12 \cdot 3$ & - \\
\hline
\end{tabular}

the end of January $13.8 \%$ of all females bear eggs at stage $a, 6.0 \%$ at stage $b$ and a few, less than $\mathrm{I} \%$, are eyed and at stage $c$. Advanced larvae at stage $d$ are present $(\mathrm{I} \cdot 8 \%)$ in the mid-February samples but females that have released their larvae are not seen until the first week in March (Table I). It appears that eggs laid at the beginning of the breeding season are carried for about IO-I2 weeks. During February there is a decrease in the number of females with recently laid eggs. The percentage of females bearing stage $a$ eggs increases during March and reaches a peak of more than $26 \%$ during April and May. There is a decrease in June and another peak is recorded in the offshore population in July. No females bearing stage $a$ eggs have been recorded after mid-July. In fact no egg-bearing females have been taken after July although a small number of females with egg remains were taken in August (Table I). Thus it would appear that eggs laid early in July hatch 5 or 6 weeks later, i.e. their development is twice as fast as those laid at the beginning of the breeding season. This increase in the rate of egg development as the breeding season advances is supported by the fact that while the greatest percentage of eggs at stage $a$ is reached in April and May, it is the June samples that show the greatest percentage of females bearing stage $d$ eggs and newly hatched larvae (14.3 and $28.6 \%$, respectively). This indicates a development time of about 7 weeks. Such a decrease in development time has been recorded by Havinga (1930) in the case of $C$. vulgaris. He calculated that the winter (October-November) brood of $C$. vulgaris at a temperature of about $9^{\circ} \mathrm{C}$ take about 9 weeks for development while the summer eggs (May-June) at a temperature of about $18^{\circ} \mathrm{C}$ develop in half that time. This relationship to temperature is by no means so clear in Northumberland waters. From December to March there is an average drop in the temperature of the offshore water close to the bottom of $9.0-5.5^{\circ} \mathrm{C}$ and inshore $9.0-5.0^{\circ} \mathrm{C}$ (Fig. 5). From March to July there is a corresponding increase in temperature from $5-10^{\circ} \mathrm{C}$ inshore and from $5.5-7 \cdot 5^{\circ} \mathrm{C}$ offshore. The range in 
temperature is much the same for the two halves of the breeding season, even though the population that is inshore at the beginning of the breeding season has moved offshore during the second half of the season. That the temperature is falling in the first period and rising in the last may be

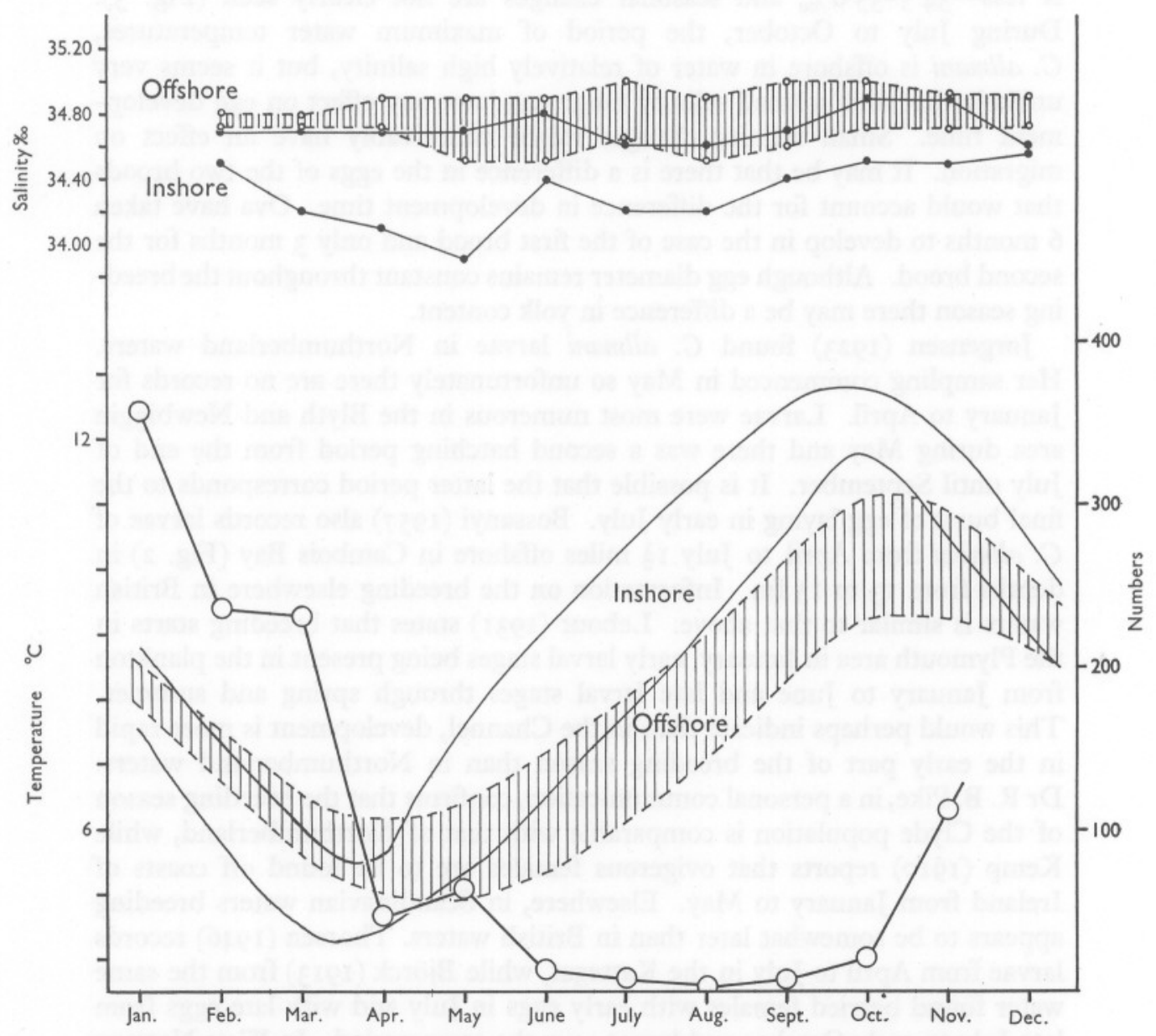

Fig. 5. The limits of salinity and temperature records from deep water inshore $(25-30 \mathrm{fm})$ and offshore $(45-50 \mathrm{fm}$.) during the years $1953-58$. The inshore average monthly catch per $20 \mathrm{~min}$ haul of C. allmani is superimposed on the hydrographic data.

of significance. Broekema (194I) finds that salinity is related to egg development time in C. vulgaris, but in the case of C. allmani salinity changes during the breeding season cannot compare with those experienced by $C$. vulgaris in shallow and estuarine waters. Broekema finds that development may be twice as long in salinity of $16 \%$ as compared with $35 \%$ in the case of 
C. vulgaris and that with increasing temperature the salinity optimum shifts towards less saline water. The maximum range in salinity of the bottom water at the inshore stations is $34-35 \%$, with minimum salinities in May and June and maximum in November and December. Offshore the range is less-34.5-35.0\% and seasonal changes are not clearly seen (Fig. 5). During July to October, the period of maximum water temperatures, C. allmani is offshore in water of relatively high salinity, but it seems very unlikely that such a small salinity range can have any effect on egg development time. Small salinity changes might conceivably have an effect on migration. It may be that there is a difference in the eggs of the two broods that would account for the difference in development time. Ova have taken 6 months to develop in the case of the first brood and only 3 months for the second brood. Although egg diameter remains constant throughout the breeding season there may be a difference in yolk content.

Jørgensen (I923) found C. allmani larvae in Northumberland waters. Her sampling commenced in May so unfortunately there are no records for January to April. Larvae were most numerous in the Blyth and Newbiggin area during May and there was a second hatching period from the end of July until September. It is possible that the latter period corresponds to the final burst of egg laying in early July. Bossanyi (1957) also records larvae of C. allmani from April to July $\mathrm{I} \frac{1}{2}$ miles offshore in Cambois Bay (Fig. 2) in depths from 13 to $15 \mathrm{fm}$. Information on the breeding elsewhere in British waters is similar to that above. Lebour (193I) states that breeding starts in the Plymouth area in January, early larval stages being present in the plankton from January to June and late larval stages through spring and summer. This would perhaps indicate that, in the Channel, development is more rapid in the early part of the breeding season than in Northumberland waters. Dr R. B. Pike, in a personal communication, confirms that the breeding season of the Clyde population is comparable with that of Northumberland, while Kemp (1910) reports that ovigerous females are to be found off coasts of Ireland from January to May. Elsewhere, in Scandinavian waters breeding appears to be somewhat later than in British waters. Thorsen (1946) records larvae from April to July in the Kattegat, while Björck (1913) from the same water found berried females with early eggs in July and with late eggs from late July to early October and larvae over the same period. In West Norway (Wollebaek, 1908) berried females are found in March and throughout the summer, the larvae hatching during the summer months.

Analysis of the length measurements of the egg bearing females shows a decrease in average length over the breeding season although the overall size range does not differ over the season (Table 3). Only three specimens with a carapace length of less than $7.5 \mathrm{~mm}$ (one at $7.1 \mathrm{~mm}$ and two at $7.4 \mathrm{~mm}$ ) were found carrying eggs. The majority of shrimps between 7.0 and $7.5 \mathrm{~mm}$ carapace length were obviously immature and this was confirmed when ovum 
length was plotted against carapace length in non-ovigerous females (Fig. 6). Examination of the testes shows that the male matures at about the same size as the females, so that for purposes of calculation shrimps below $7.5 \mathrm{~mm}$ carapace length are classified as immature.

TABLE 3. THE CARAPACE LENGTH IN MM OF FEMALE CRANGON ALLMANI BEARING EGGS FOR EACH MONTH OF THE BREEDING SEASON

\begin{tabular}{|c|c|c|c|c|c|}
\hline & Average & Range & & Average & Range \\
\hline Dec. & 10.5 & (10.5) & Apr. & $9 \cdot 8$ & $(6 \cdot 9-12 \cdot I)$ \\
\hline Jan. & II. 3 & $(8 \cdot 0-16 \cdot 0)$ & May & $9 \cdot 3$ & $(7 \cdot 7-13 \cdot 2)$ \\
\hline Feb. & IO. I & $(7 \cdot 4-14 \cdot 8)$ & June & $9^{6} 6^{\star}$ & $(7 \cdot I-I I \cdot I)$ \\
\hline Mar. & 10.3 & $(7 \cdot 9-16.9)$ & July & $9 \cdot 6$ & $(7 \cdot 9-12 \cdot 4)$ \\
\hline
\end{tabular}

* Calculated on less than thirty specimens.

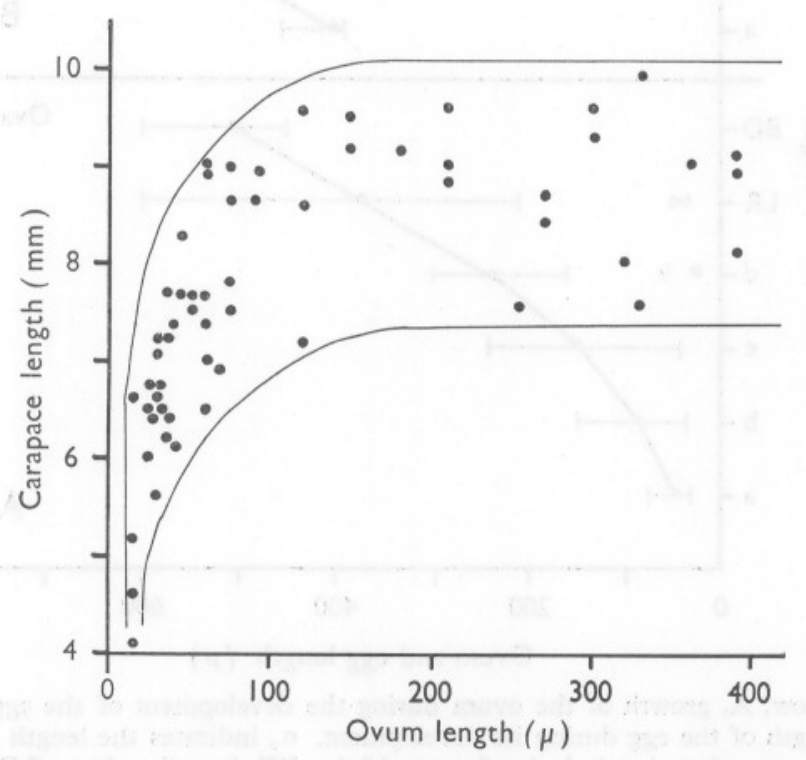

Fig. 6. Carapace length plotted against ovum length in females that have yet to lay eggs.

Little growth of the ova occurs before $C$. allmani reaches $5.5 \mathrm{~mm}$ carapace length. There is a marked increase in the rate of growth of the ova after the shrimp has grown to $6.5 \mathrm{~mm}$ and exceptionally eggs are laid soon after it reaches $7.0 \mathrm{~mm}$ carapace length (Fig. 6). The majority of the females do not develop so fast and first lay their eggs when the carapace measures between 8.5 and $9.5 \mathrm{~mm}$. As the breeding season extends over 7 months and there appear to be two, or possibly three, peaks of egg laying, it was necessary to find whether the shrimps lay more than one brood during the season. Ovum length was plotted against stages in egg development (Fig. 7). Not all the ova are released at the time of the first egg laying. There remains a core of small ova 
each approximately $50 \mu$ long that increases rapidly in size during the period of egg carriage so that when the larvae are released a second brood is almost ready to be laid, the ova being approximately $370 \mu$ long. In Pandalus borealis (Allen, 1959) the growth rate of the ovum in the latter half of its development in the ovary was shown to be a straight line. This also appears to be the

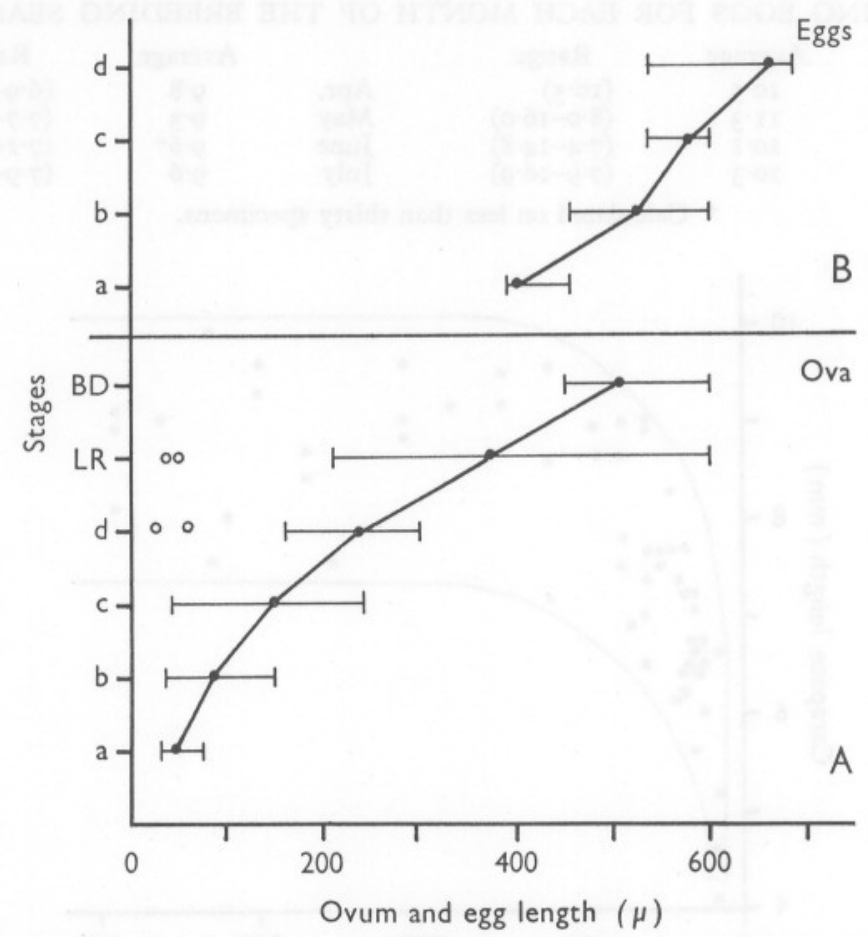

Fig. 7. To show, A, growth of the ovum during the development of the egg and, B, the increase in length of the egg during its development. $\circ$, indicates the length of the ova in females with eggs ready to hatch during June and July. BD, breeding dress; LR, egg remains following the release of the larvae; see p. 483 for explanation of stages $a, b, c$ and $d$.

case in C. allmani and extrapolation of the graph indicates that the interval between release of the larvae and the re-assumption of breeding dress and the second egg laying is of the order of 2 or 3 weeks. The growth rate of the ova of egg-bearing females in the June and July samples is not rapid. The reduction in the growth rate is maintained during the late summer and autumn and the ova take 6 or 7 months to reach maturity as compared with 3 months for the second brood of the season (Fig. 8).

The ovary of the immature shrimp extends from the posterior end of the stomach to the dorsal posterior limit of the carapace, while that of the female with mature ova extends from the anterior limit of the carapace to the centre 
of the third abdominal segment. Egg laying usually occurs shortly after the assumption of breeding dress. Most of the females caught in breeding dress were soft and so were many with newly laid eggs. The newly laid eggs are a transluscent gold colour and are remarkably constant in size irrespective of differences in the time taken for the ova to mature. They are spherical when first laid with a diameter of $390 \mu$. The eggs soon elongate and continue to do so throughout their development. Immediately before hatching the egg case

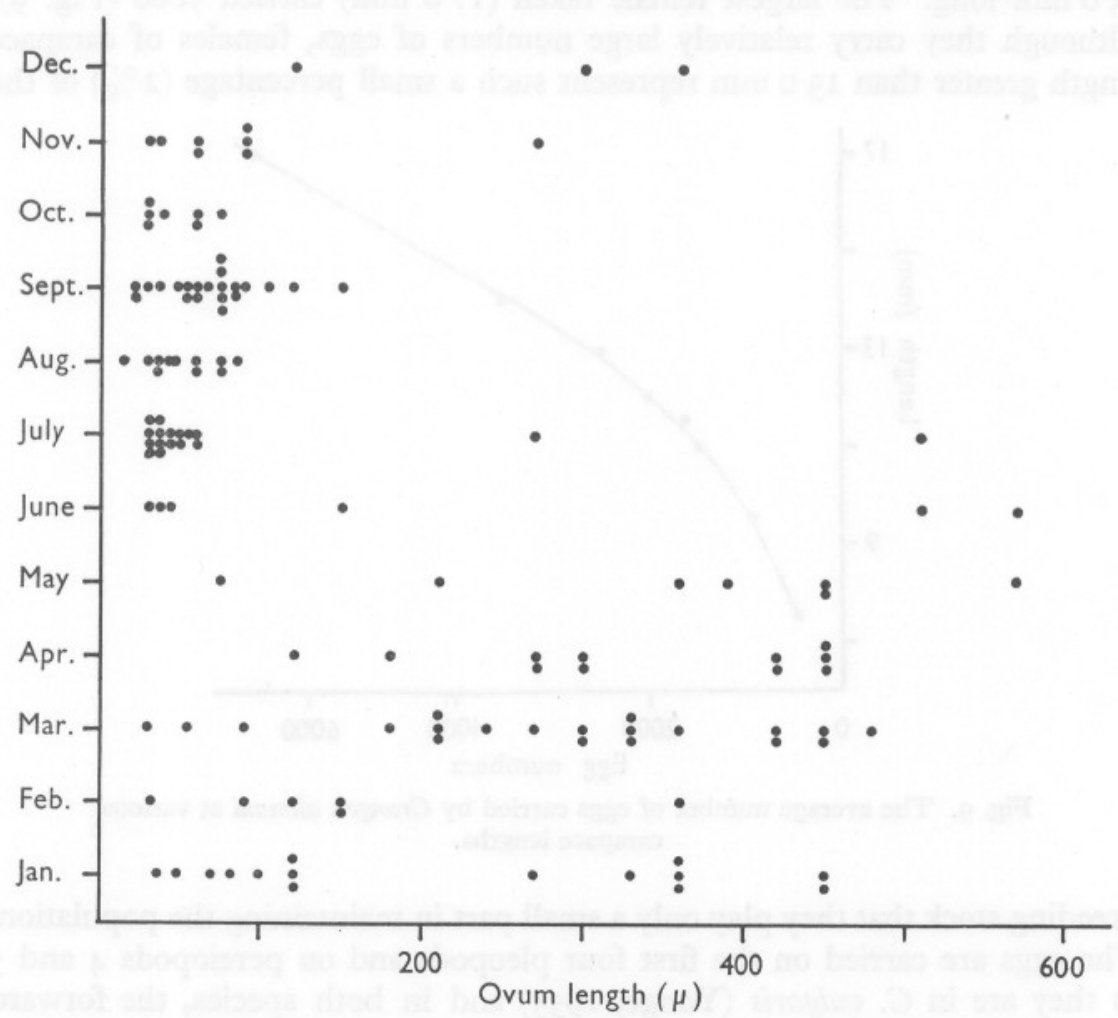

Fig. 8. Maximum ovum lengths in ovigerous females, or non-ovigerous females that have had at least one brood of eggs, plotted against month of capture.

is approximately $650 \mu$ long (Fig. 7). It will be noticed (Figs. 7, 8) that the length of the mature ovum is greater than the diameter of the newly laid egg. This is due to the compression of the ovum within the ovary producing an elongate, angular shape.

Høglund (I943) shows that owing to the weakly developed epimera, short basipodites and endopodites, with the latter lacking stylamblys, the eggs of Crangon are more exposed and unprotected than those of any other caridean. This makes heavy demands on the fixing system and in Crangon the ovigerous 
setae and the cement are particularly strong. Nevertheless, the eggs of C. allmani are easily detached and the possibility of loss increases with age as the developing eggs enlarge with the resulting increase in volume of the egg mass. Many shrimps with advanced eggs appeared to have considerably reduced numbers and for this reason egg counts were taken only in the case of females with stage $a$ eggs. The average egg count for females with a carapace length of $7.5 \mathrm{~mm}$ is 400 and this increases to approximately 2500 on a shrimp I3.0 $\mathrm{mm}$ long. The largest female taken (17.0 mm) carried 7060 (Fig. 9). Although they carry relatively large numbers of eggs, females of carapace length greater than $13.0 \mathrm{~mm}$ represent such a small percentage $(2 \%)$ of the

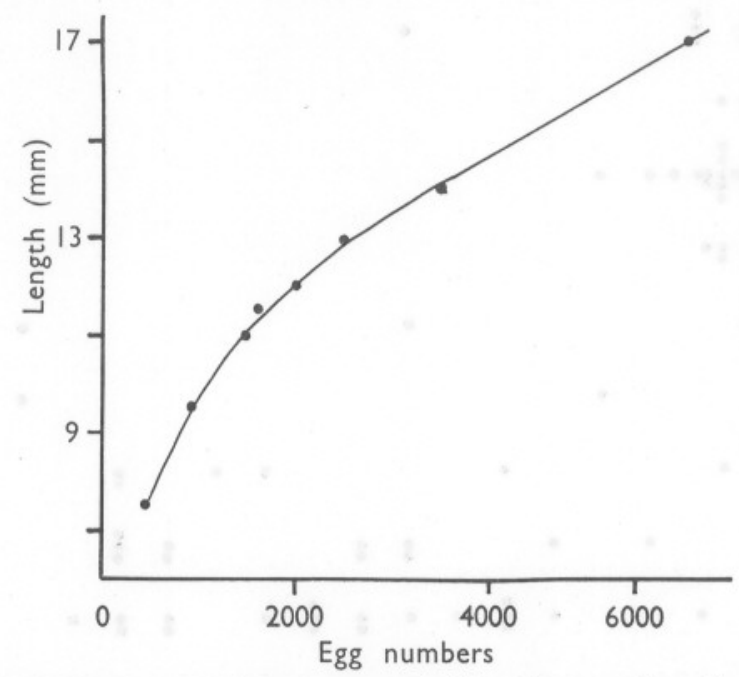

Fig. 9. The average number of eggs carried by Crangon allmani at various carapace lengths.

breeding stock that they play only a small part in maintaining the population. The eggs are carried on the first four pleopods and on pereiopods 4 and 5 as they are in C. vulgaris (Yonge, 1955) and in both species, the forward extension of the egg mass under the thorax is probably a modification related to the bottom feeding.

\section{GROWTH}

A prolonged breeding season with three breeding maxima makes it very difficult to decipher the monthly population histograms for the purpose of abstracting information on rate of growth (Figs. 3, 4). Furthermore, owing to the size of net used, few $C$. allmani smaller than $6.0 \mathrm{~mm}$ carapace length were caught. Dredge samples secured a few young C. allmani mainly during the months July to September. These had an average carapace length of $3.5 \mathrm{~mm}$. As the carapace length of the newly metamorphosed C. allmani 
must be of the order of $2.0 \mathrm{~mm}$ (the last larval stage is $6.5 \mathrm{~mm}$ long-Lebour, I93I), there can be little doubt that these are recently hatched o-group. This group appeared in the trawl hauls inshore in November when a few females between $4^{\circ} 0$ and $6.0 \mathrm{~mm}$ carapace length were caught. By January the average carapace length of the o-group is $6.0 \mathrm{~mm}$ (Fig. I0). Although the youngest C. allmani are too small to be retained in the net in any numbers, a few specimens below $6.5 \mathrm{~mm}$ carapace length are caught throughout the year and it is probable that recruitment is continuous from April to October with the main peak from July to September. The only samples showing two clearly defined population peaks are those offshore in September (Fig. 4). One peak has an

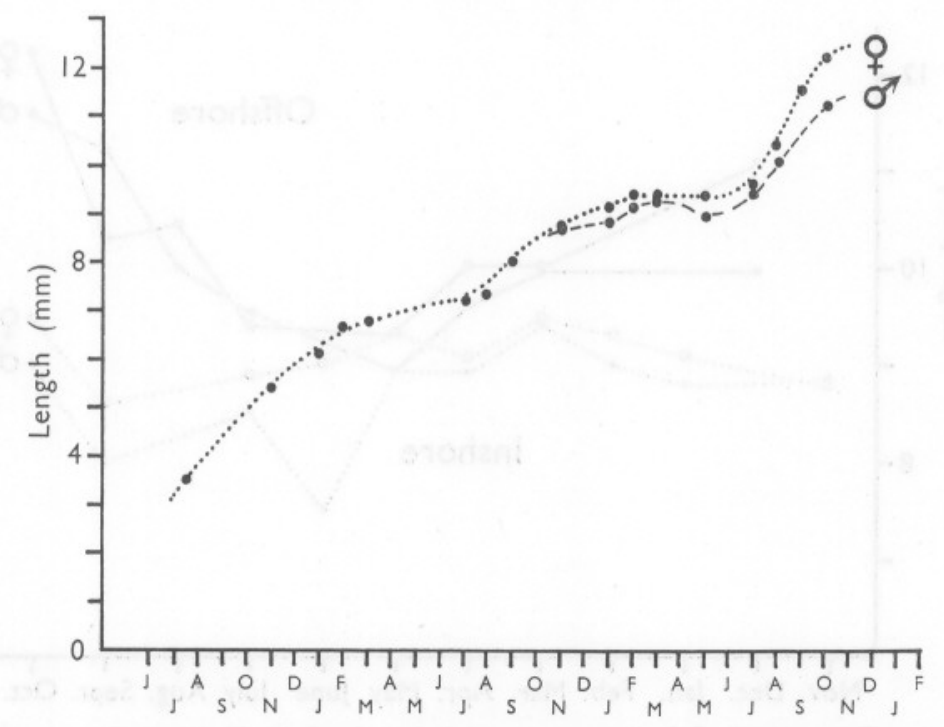

Fig. ro. The probable growth-rate curve of male and female Crangon allmani during their normal life span: mean carapace length plotted over a period of $2 \frac{1}{2}$ years.

average carapace length of $8.0 \mathrm{~mm}$ (I-group) and the other II $5 \mathrm{~mm}$ (2-group). Peaks corresponding to the $8 \mathrm{~mm} \mathrm{I-group} \mathrm{are} \mathrm{not} \mathrm{seen} \mathrm{in} \mathrm{histograms} \mathrm{of} \mathrm{off-}$ shore samples in the following months and it is probable that this group migrates inshore during October and forms the greater part of the inshore population in the November samples (Fig. 3). This population has an average carapace length of $8.7 \mathrm{~mm}$. November is the first month following the seasonal disappearance when $C$. allmani is taken in large numbers inshore. Some of the larger 2-group C. allmani also move inshore, mainly during December and January. Owing to the small numbers involved, differences between the rates of growth of males and females, are not apparent in shrimps less than $7.5 \mathrm{~mm}$. The females of the inshore samples (mainly I-group) from January to May show little increase in size, the average carapace length being $9.3 \mathrm{~mm}$. This 
lack of growth is no doubt due to the cessation of moults while egg bearing. The effect of the growth of shrimps maturing for the first time and also the continued entry of o-group into the catches is offset by the interbrood growth. There is a gradual but slow increase in the average size of the males during January to March $(8 \cdot 8-9.3 \mathrm{~mm})$ followed by a drop in April and May $(8.9 \mathrm{~mm})$. This drop is probably due to the effect of the offshore migration. During April and May the inshore population almost completely disappears, and it is probably significant that May is the only month in which the average length of the inshore and offshore populations is the same (Fig. II). During the rest of the year the average length of the offshore population is greater

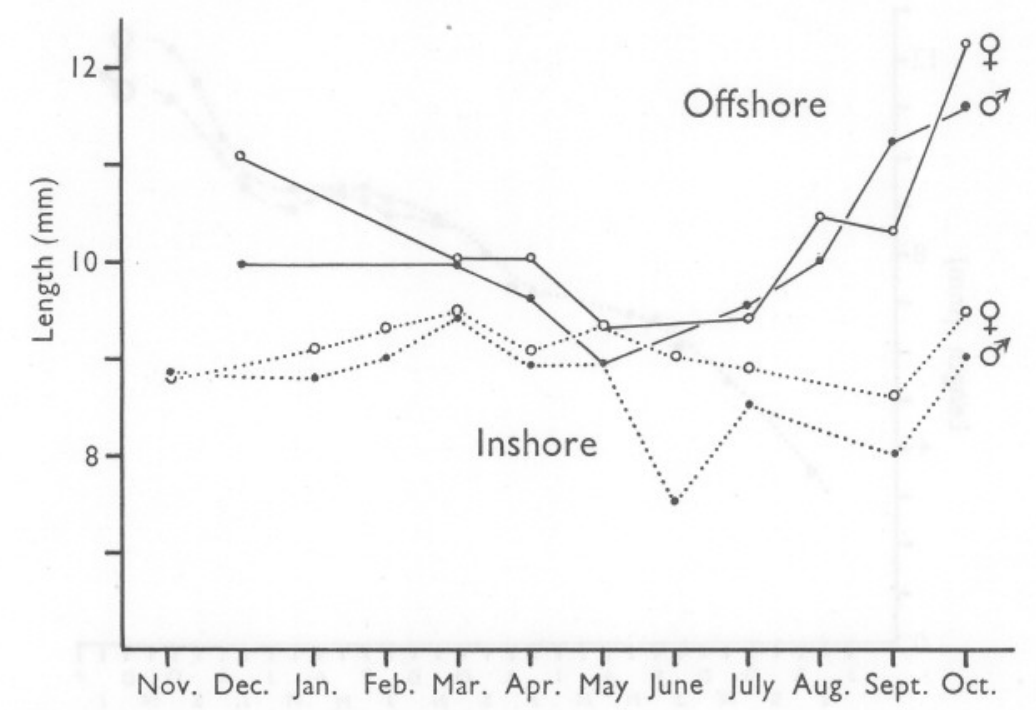

Fig. II. Comparison of the average carapace length of the Crangon allmani caught inshore and offshore throughout the year.

than the inshore. In the period May to October a few C. allmani remain inshore. These are mostly small females about 8.5-9.0 $\mathrm{mm}$ carapace length (Table 7). During the same period offshore there is a steady increase in the average length of the population (Figs. 4 \& II), and by the end of the period the original I-group and o-group have become the new 2-group and I-group, respectively. The new 2-group reaches a maximum average size of $12.5 \mathrm{~mm}$ in November, after which there is a drop probably due to the death of the largest shrimps following early spring breeding (see below).

Throughout life the male $C$. allmani is slightly smaller than the female. The females of the new brood are the first to appear in the catches, but the difference in the average carapace lengths is never greater than $\mathrm{I} .0 \mathrm{~mm}$ in the oldest shrimps. Comparison of the mean lengths of the males and females of 
each haul does not necessarily give a true figure for this difference in size. The two sexes appear to migrate at different times with the result that in some samples (e.g. offshore, September) the average length of the male is greater than the female (Fig. II). Although most of the $C$. allmani die in their third year a few live at least one more year. The largest female caught was $17.0 \mathrm{~mm}$ carapace length and the largest male $14.0 \mathrm{~mm}$. The male probably dies before the female, soon after copulation. Further examination of the data suggests that many 2-group shrimps which form a large part of the breeding stock during December to March die and do not breed a second time. It is interesting to note that Wollebaek (1908) reports that the average size of C. allmani in Norwegian waters is larger than that of C. vulgaris (100 $\mathrm{mm}$ as to $60-70 \mathrm{~mm}$ ). The reverse is true in British waters.

\section{MOULTS}

The records of recently moulted shrimps show no significant difference between males and females from inshore or from offshore grounds. On the average, $4 \%$ of all C. allmani have recently moulted. There is some difference between the samples taken between January and June $(3.1 \%)$ and July to December $(6.6 \%)$. Such a difference might be expected as the former period covers the breeding season when egg bearing restricts moulting while the latter is the period of maximum growth when the new year group is entering the stock. Most of the specimens in breeding dress are soft as are many of the females bearing newly laid eggs. The data give no indication how frequently C. allmani moults, except that $9.0 \%$ of those less than $8.0 \mathrm{~mm}$ carapace length, $4.8 \%$ of those between 8.1 and $10.0 \mathrm{~mm}$ and $3.4 \%$ of those greater than IO. I mm had recently moulted.

In the interval between successive broods there is a moult to dispose of the old breeding dress and egg remains followed by re-assumption of breeding dress within a maximum of 3 weeks. It is known that the moult frequency of other Caridea of similar size is about 20-35 days (Nouvel \& Nouvel, I937; Høglund, I943) so that it seems unlikely that there are intermediate moults between the losing of the old and the gaining of the new breeding dress.

\section{FOOD}

The analysis of the stomach contents of more than 350 C. allmani is shown in Tables 4 \& 5. Approximately $54 \%$ had food in the stomach. It will be seen from Table 4 that there is little difference in the percentages of shrimps with and without food in respect of sex and of maturity of the gonads. Females, with mature gonads taking all the available space in the thorax, had food present. Only in newly moulted shrimps was food invariably absent. Identification of the food proved far from easy as the mandibles (Fig. I2), which are both large and efficient, break the food into small fragments. 
TABLE 4. THE PERCENTAGE OF CRANGON ALLMANI WITH FOOD PRESENT IN THE STOMACH WITH RESPECT TO SEX AND MATURITY

\begin{tabular}{|c|c|c|c|}
\hline & $\begin{array}{l}\text { Number } \\
\text { examined }\end{array}$ & $\begin{array}{l}\text { Percentage } \\
\text { with food }\end{array}$ & $\begin{array}{c}\text { Percentage } \\
\text { without food }\end{array}$ \\
\hline Male & 150 & $52 \cdot 7$ & $47 \cdot 3$ \\
\hline Female & 200 & $55^{\circ} 0$ & $45^{\circ} \mathrm{O}$ \\
\hline Immature testis & 82 & $57 \cdot 7$ & $43 \cdot 3$ \\
\hline Mature testis & 68 & $50 \cdot 0$ & $50 \cdot 0$ \\
\hline Females without eggs & I47 & & \\
\hline With ova length $<$ I50 $\mu$ & IOI & $52 \cdot 5$ & $47 \cdot 5$ \\
\hline With ova length $>\mathrm{I} 50 \mu$ & 46 & $56 \cdot 5$ & $53 \cdot 5$ \\
\hline Females with eggs & 52 & $55 \cdot 8$ & $44 \cdot 2$ \\
\hline
\end{tabular}

The sample is representative of the size range.

C. allmani feeds predominantly on living Crustacea and Annelida. Mollusca, Foraminifera and Ophiuroidea are present in smaller quantities, while Whiting scales were present in a few stomachs. Sand and mud particles are always present with the food. In the laboratory the shrimp behaves in much the same way as $C$. vulgaris (Lloyd \& Yonge, 1947), burrowing and searching in the top few millimetres of the substratum. Occasional specimens were taken with a small Nephthys held by the mouth parts. The chelae, maxillae and maxillipeds appear to be used for grasping and guiding the food into the mouth, the mandibles alone are used in mastication, although Havinga (1929) refers to 'chewing teeth' on the first maxilla in C. vulgaris. Identifiable annelidan remains consist of Nephthys (ca. $90 \%$ ) and Glycera (ca. 10\%). The crustacean remains are more varied and consist of small Cumacea, Amphipoda, Copepoda and young $C$. allmani. Of the identifiable Mollusca the most common were Dosinia lupinus, Venus striatula and Cylichna cylindracea.

TABLE 5. PERCENTAGES OF DIFFERENT TYPES OF FOOD ORGANISMS PRESENT IN STOMACHS OF CRANGON ALLMANI FROM INSHORE AND OFFSHORE STATIONS

\begin{tabular}{|c|c|c|c|c|}
\hline & \multicolumn{2}{|c|}{ Inshore } & \multicolumn{2}{|c|}{ Offshore } \\
\hline & $\hat{0}$ & 우 & 0 & q \\
\hline Crustacea & $65 \cdot 6$ & $68 \cdot I$ & $55 \cdot 6$ & 63.9 \\
\hline Annelida & $43 \cdot I$ & $43 \cdot I$ & $59 \cdot 3$ & $6 \mathrm{I} \cdot \mathrm{I}$ \\
\hline Mollusca & $12 \cdot 1$ & $16 \cdot 7$ & $7 \cdot 4$ & $5 \cdot 6$ \\
\hline Foraminifera & 3.9 & $4 \cdot 2$ & $I I \cdot I$ & - \\
\hline Ophiurida & $1 \cdot 7$ & I. 4 & - & - \\
\hline Whiting scales & $6 \cdot 9$ & $4 \cdot 2$ & - & - \\
\hline Without food & $43 \cdot 6$ & $43 \cdot 7$ & $44 \cdot 9$ & $49 \cdot 4$ \\
\hline With food & $56 \cdot 4$ & $56 \cdot 3$ & $55 \cdot 1$ & 50.6 \\
\hline
\end{tabular}

Comparison of the stomach contents of the inshore and offshore populations shows a few differences. About $65 \%$ of the shrimps with food in the stomach have crustacean remains, with little difference between the two populations. Significantly more worms are eaten offshore $(60 \%)$ than inshore 
$(43 \%)$, while more molluscs are eaten inshore than offshore (Table 5). Other food organisms are in too small quantity to make any comparison except that it should be noted that Whiting scales were only present in the stomachs of C. allmani from the inshore stations. There is no significant difference between the diet of the male and the female.

Analysis of food with respect to size and month of capture shows little variation in either case except that the smaller size groups have a high proportion of copepods in their crustacean food.

\section{EXTERNAL MORPHOLOGY}

The woodcuts of $C$. allmani illustrating the original descriptions by Kinahan (I857, I86I) are not accurate. They were improved upon by the photographs and drawings of Wollebaek (1908); but unfortunately these are poorly reproduced and, in addition to a hazy dorsal view of the shrimp, include only the first antenna, chela and sixth abdominal segment. A series of drawings of the external features of C. allmani has been included to fill this gap (Figs. I2I4). Little need be said in the way of description except that contrary to the account given by Kinahan (I857) there is a well-developed spine on the meropodite of the chela, as in $C$. vulgaris. The differences between $C$. vulgaris and C. allmani have been discussed by Wollebaek (1908) and the present study supported his findings.

Although the male pleopods are generally more setose than those of the female, except when the latter is in breeding dress, the only reliable method of sexing C. allmani short of dissection is by microscopic examination of the first and second pleopods. In practice the second pleopod was examined. The endopodite of the second pleopod of the male bears an appendix masculina above the base of its inner edge. In the smallest specimens (Fig. I4) the appendix masculina is small and easily overlooked. It is in the form of a small projection from the inner edge of the second segment and bears a single seta at its tip. The appendix increases in size and at maturity has 6 or 7 setae along its inner edge. In the oldest males an additional 6 or 7 setae are attached to the base of the organ. The second pleopod of the female is without an appendix. The endopodite of the first pleopod of the male differs in shape to that of the female (Fig. I4). In the smallest males it is blade shaped with three setae at the tip. As it increases in size the setae become more numerous, 6 or 7 at maturity and many more prior to copulation. It becomes more pointed with age. The endopodite of the female (Fig. I4) is similar in many respects to that of the male, but it is always more elongated and becomes progressively more so with increasing age. Except when the female is in breeding dress there are never more than three short setae present along the inner edge. On assumption of breeding dress the endopodite of the first pleopod, and those of pleopods 2-4, are much modified with numerous 
ovigerous setae and long pinnate setae. The pattern of ovigerous setae is similar to that described by Yonge (1955) for $C$. vulgaris (Table 6) and the number of these setae varies with the size of the shrimp. The specimen of C. vulgaris chosen for comparison in Table 6 is $55 \mathrm{~mm}$ long, mature females ranging in size from 45 to $70 \mathrm{~mm}$ while $C$. allmani is $37 \mathrm{~mm}$ with a range of 26-54 mm.

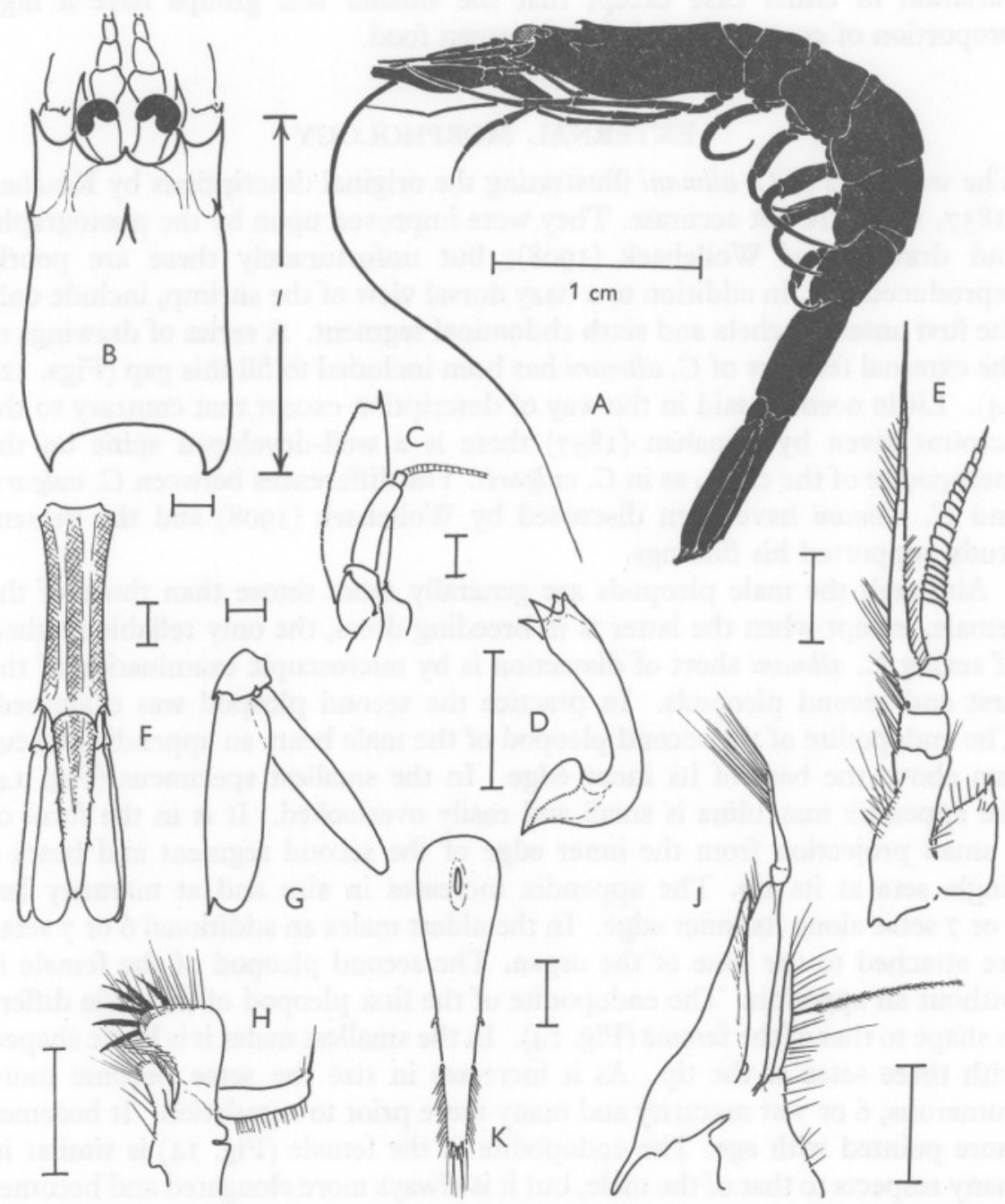

Fig. I2. External morphology of a male Crangon allmani. A, lateral view of the animal; B, dorsal view of the carapace with the measurement of length (l) indicated; C, peduncle of the and antenna and its scale, setae not shown; D, mandible; E, Ist antenna; F, dorsal view of the 6th abdominal segment, telson and uropods; G, uropod, setae not shown; H, Ist maxilla; $\mathrm{J}$, Ist maxilliped; $\mathrm{K}$, ventral view of the telson. Except for $\mathrm{A}$, all scales represent $\mathrm{I} \mathrm{mm}$. 


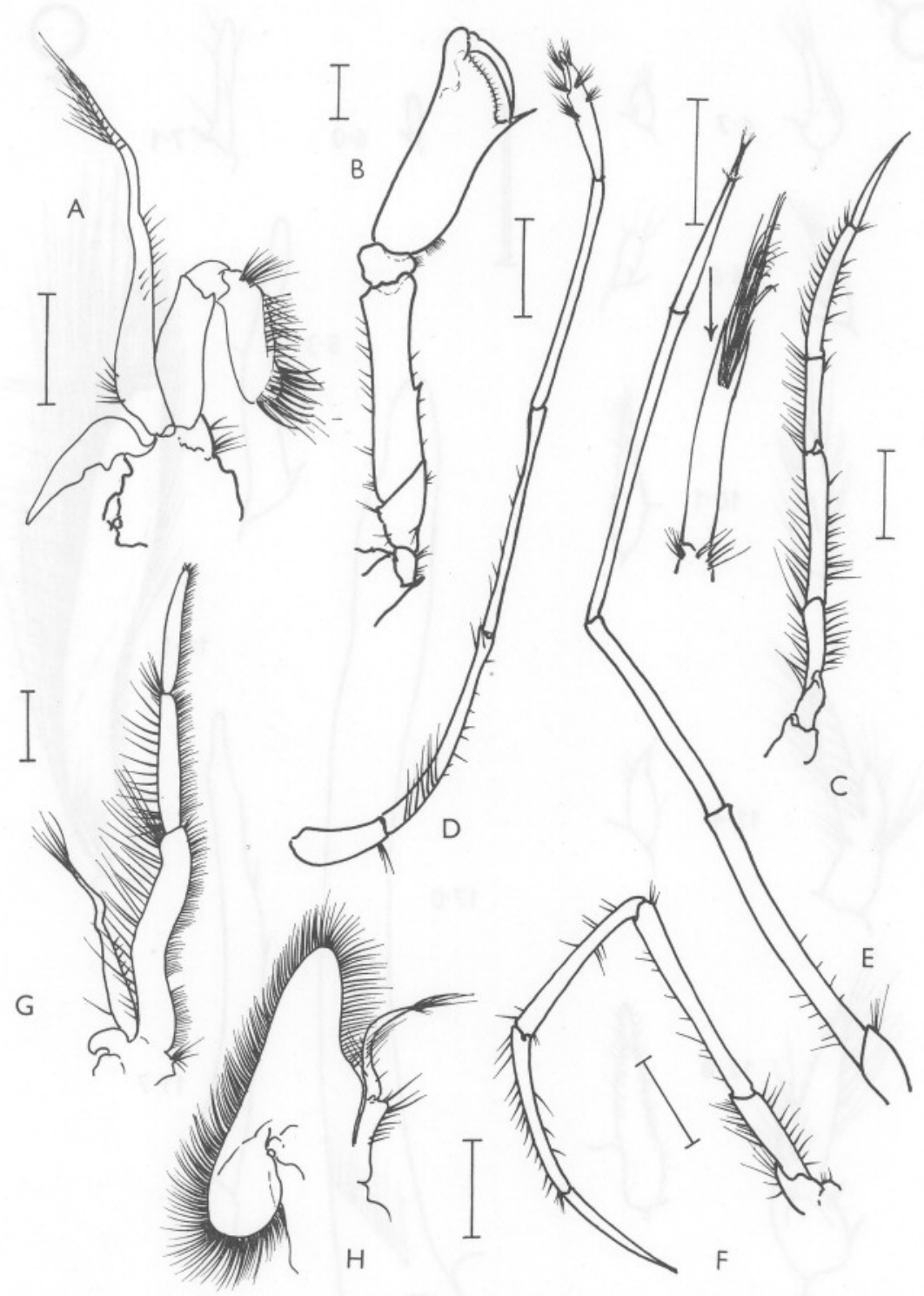

Fig. 13. External morphology of a male Crangon allmani continued. A, 2nd maxilliped; B, Ist pereiopod; C, 4 th pereiopod; D, 2nd pereiopod; E, 3 rd pereiopod; F, 5 th pereiopod; G, 3rd maxilliped; $\mathrm{H}$, 2nd maxilla. All scales represent $\mathrm{I} \mathrm{mm}$. 


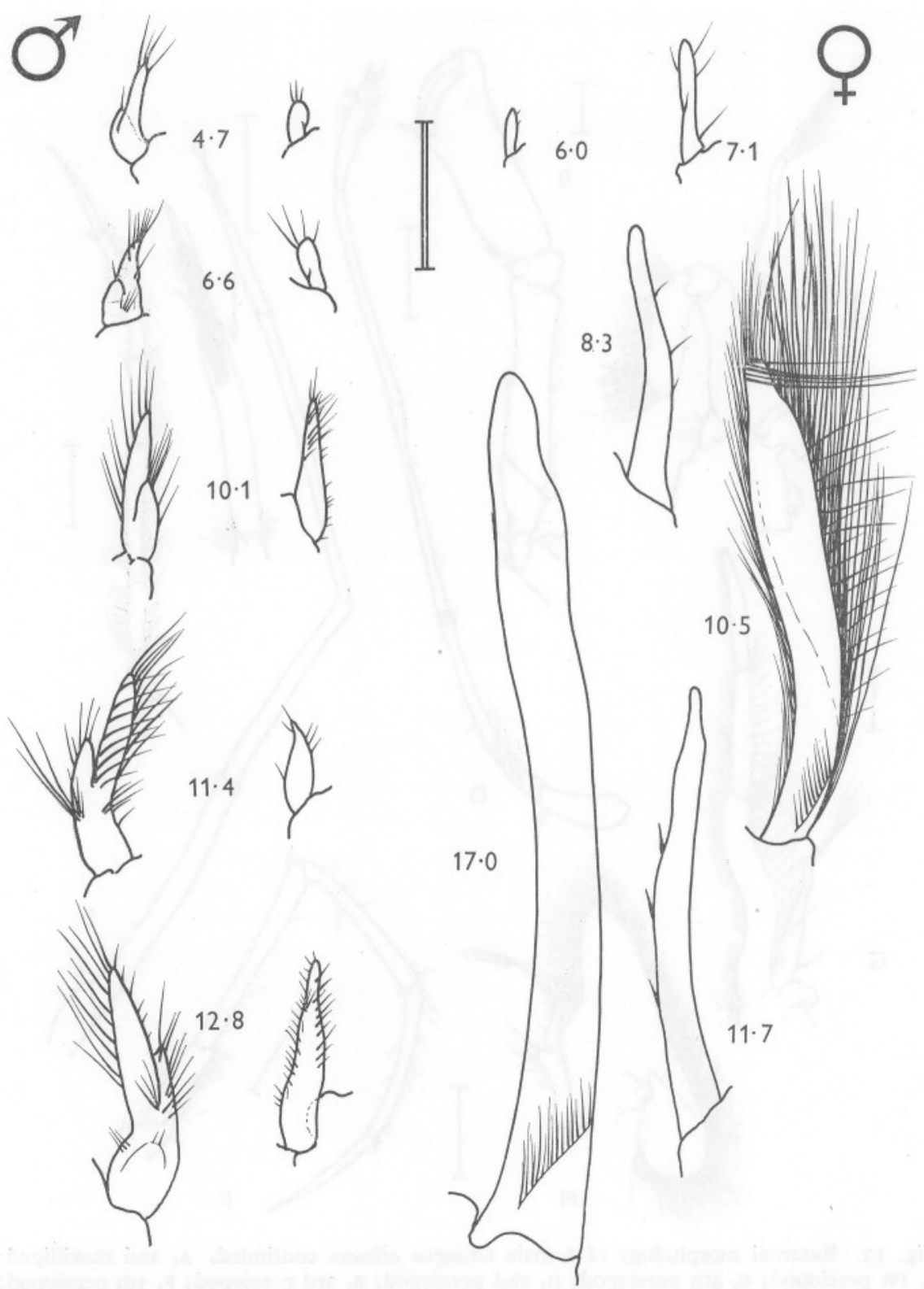

Fig. 14. The development of the endopodite of the Ist and 2nd pleopods of the male and the rst pleopod of the female Crangon allmani. The carapace length of the specimens from which they were taken is indicated at the side of each appendage. The males measuring IO.I and 12.8 $\mathrm{mm}$ have ripe gonads. The females measuring 10.5 and $17.0 \mathrm{~mm}$ are in breeding dress, the setae in the latter being omitted. The scale represents $\mathrm{I} \mathrm{mm}$. 
TABLE 6. COMPARISON OF THE NUMBERS OF OVIGEROUS SETAE ON THE PLEOPODS OF CRANGON VULGARIS AND C. ALLMANI OF COMPARABLE SIZE (SEE TEXT p. 500)

\begin{tabular}{|c|c|c|c|c|c|c|c|c|}
\hline \multirow{2}{*}{$\begin{array}{l}\text { Groups } \\
\text { of setae }\end{array}$} & \multicolumn{4}{|c|}{$\begin{array}{l}\text { C. vulgaris } \\
\text { Pleopods }\end{array}$} & \multicolumn{4}{|c|}{$\begin{array}{l}\text { C. allmani } \\
\text { Pleopods }\end{array}$} \\
\hline & I & 2 & 3 & 4 & $\begin{array}{lll}\text { I } & \end{array}$ & 2 & 3 & 4 \\
\hline C & - & - & - & - & - & - & - & - \\
\hline Bp & 6 & 5 & 5 & 5 & 5 & 5 & 5 & 2 \\
\hline $\begin{array}{l}\text { Bpa } \\
\mathrm{Bm}\end{array}$ & I0 & $3-4$ & 4 & 2 & $8-9$ & 5 & $\begin{array}{l}4 \\
6\end{array}$ & 3 \\
\hline $\begin{array}{l}\mathrm{Bm} \\
\mathrm{Bd}\end{array}$ & $\begin{array}{l}8 \\
5\end{array}$ & 8 & 8 & - & 6 & 6 & 6 & - \\
\hline $\begin{array}{l}\mathrm{Bd} \\
\mathrm{Bda}\end{array}$ & $\begin{array}{l}5 \\
3\end{array}$ & 4 & $\underline{4}$ & 二 & 4 & $\underline{4}$ & 4 & 二 \\
\hline E & $19-22$ & 二 & $=$ & 二 & $\overline{2 I}$ & $=$ & $=$ & 二 \\
\hline
\end{tabular}

Data on C. vulgaris abstracted from Yonge (1955). The lettering of the groups of ovigerous setae is the same as that used by Yonge (I955). The groups are on the coxopodites (C); the proximal $(\mathrm{Bp})$, middle $(\mathrm{Bm})$ and distal $(\mathrm{Bd})$ regions of the inner margin of the basipodite and also on the anterior face in the proximal (Bpa) and distal (Bda) regions; on the endopodite (E).

\section{DISCUSSION}

It would seem that the disappearance of the inshore population during April and May until the following October can be explained by one or more of the following: deep burrowing, mortality, migration.

There is no evidence that the inshore population of $C$. allmani burrows deeper into the substratum during this period. They have not been found by extensive dredging with a variety of methods that sample the substratum to a depth of ro in. Animals caught in April and kept in the aquarium show no change in burrowing habits. Similarly, there is no evidence for large-scale mortality. It seems possible that early breeding $C$. allmani of carapace length greater than $12.0 \mathrm{~mm}$ may die about May but these prawns represent less than $2 \%$ of the total population. Furthermore, the disappearance takes place at the height of the breeding season. Many females bear eggs at stages $a$ and $b$ at this time and it seems unlikely that these will die before releasing their larvae. By elimination of the other possibilities it seems likely that a migration is the explanation of the disappearance. The North Sea populations of the closely related $C$. vulgaris migrate inshore during May and migration is a feature of the life histories of Crago francicorum and C. nigricauda (Israel, 1936). Sampling shows that the Crangon allmani do not accompany C. vulgaris into shallow water nor are they present on the vast areas of rock that are close to the inshore stations. The only area in which C. allmani is found in large numbers from May to October is in depths of $40 \mathrm{fm}$. and over. Further indirect evidence of an offshore migration is that May is the only month in which the inshore and offshore populations have the same average length (see p. 496). Havinga (I929, I930) and Broekema (I94I) show that the largest specimens of $C$. vulgaris tend to remain in deeper water, the smallest specimens migrate first and those furthest inshore are predominantly females. C. allmani parallels its relative. Females predominate the inshore population 
(Table 7), the average length of the first large inshore samples in November is smaller than those taken later in the inshore period and average length of the offshore samples is higher than those from inshore. It seems a reasonable assumption that the variations in the distribution of C. allmani are best explained by an inshore migration in October and an offshore migration in April and May.

TABLE 7. AVERAGE MONTHLY RATIO MALES/FEMALES AT INSHORE STATIONS

$\begin{array}{llll}\text { Jan. } & 0.48 & \text { July } & 0.33 \\ \text { Feb. } & 0.55 & \text { Aug. } & 0.25 \\ \text { Mar. } & 0.89 & \text { Sept. } & 0.62 \\ \text { Apr. } & 0.94 & \text { Oct. } & 1.38 \\ \text { May } & 0.75 & \text { Nov. } & 0.98 \\ \text { June } & 0.15 & \text { Dec. } & ?\end{array}$

Broekema (194I) finds that the seasonal movements of $C$. vulgaris are related to temperature and salinity. In the case of $C$. allmani the relationship of migration to these two factors is not so clear (see p. 489). Temperature and salinity data of deep water inshore and offshore off the Northumberland coast are given in Fig. 5. From this it is seen that offshore migration coincides with inshore minimum temperature. Little can be said of the salinity data except that offshore migration is into water of higher salinity.

Summary of the yearly cycle. In August the C. allmani population off Northumberland coast is in deep water (40-50 fm.) I0-15 miles off the coast. This population consists of three main age groups: o-group, newly metamorphosed shrimps, I-group, shrimps between I and I $\frac{1}{2}$ years most, if not all, have yet to breed and, 2-group, shrimps $2-2 \frac{1}{2}$ years that have laid at least two batches of eggs (Fig. I5). In addition there may be a few older female shrimps. During late September and October an inshore migration commences that coincides with the upper temperature limit of the offshore deep water. The smallest o-group and I-group shrimps tend to migrate first and although 2-group take part in the migration many remain in deep water. Similarly, some o-group and I-group shrimps remain in deep water throughout the year, but the average length of the offshore population is higher than that of the inshore population. The predominance of young shrimps inshore during October to January shown by trawl sampling is confirmed by Goonewardene who in his analysis of the stomach contents of the Whiting (see p. 487) found that he could divide the $C$. allmani into two size-groups, the smaller predominating in the catches from September to January.

During September to December the gonads of I-group and 2-group mature. The larger shrimps of each group mature first and egg laying commences in the second half of December and continues until the beginning of July. Although a quarter of the mature females lay their eggs in December and January the majority first lay their eggs between March and May. As a second batch of eggs is laid soon after the first hatch, many of the females 
that bred early in the season will be included in the May breeding population. A third smaller breeding peak in June is probably composed of late spawners with their second brood and, possibly, the largest o-group females that are a little over a year old. The larvae hatch in IO-12 weeks at the beginning of the breeding season and in 5-6 weeks at the end. Most of the 2-group shrimps

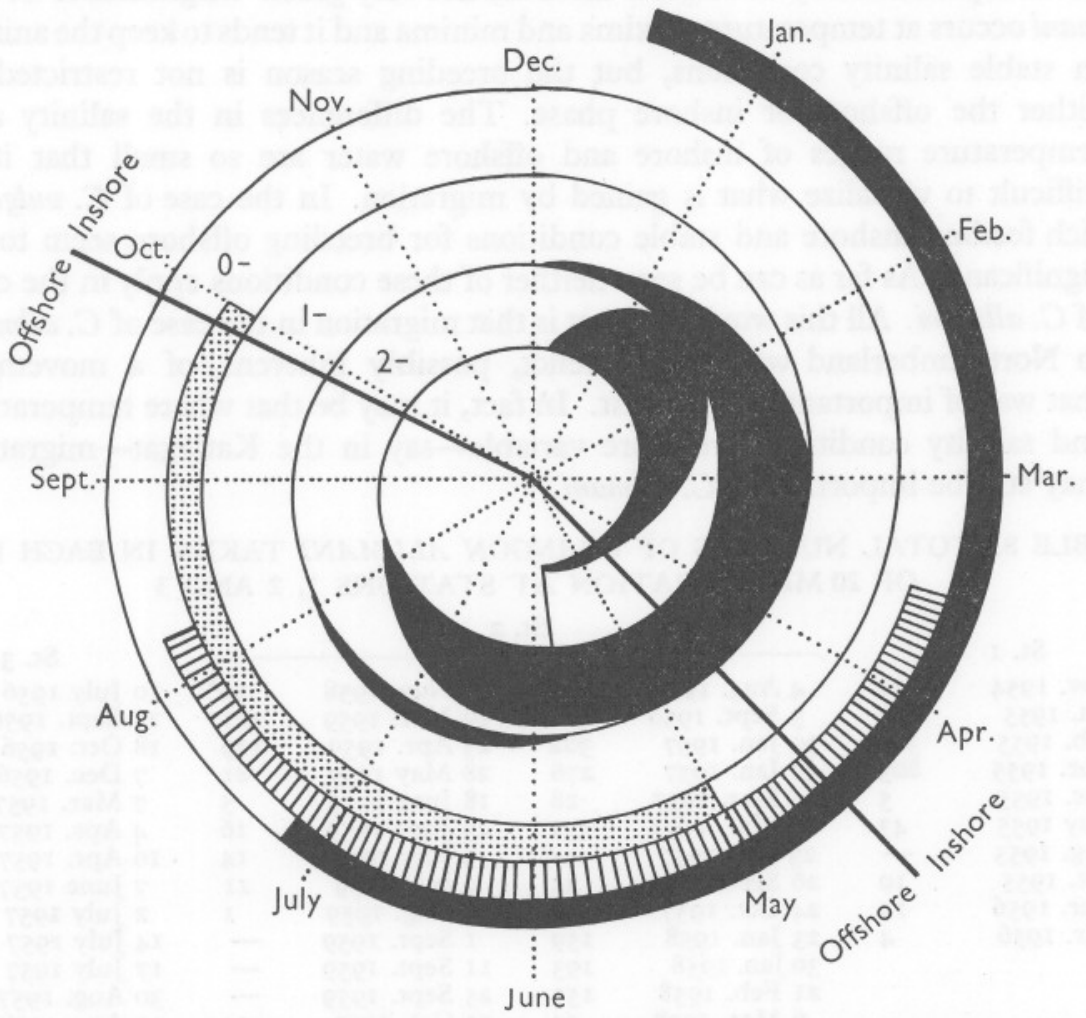

Fig. 15. Diagram representing the life cycle of a year-group. The outer black area is the period when the eggs forming the group were laid. The cross-hatched area is the period when the larvae were released and the dotted area when metamorphosis occurs. The inner black areas represent the period of egg-laying following maturity. The width of these areas gives some indication of the proportion of females with broods.

have died by the end of the breeding season (August) while newly metamorphosed larvae have joined the population. During April most of the C. allmani return to the deeper water, the movement coinciding with the minimum inshore temperature. A few smaller females remain inshore.

The life histories of $C$. allmani and $C$. vulgaris are very similar. The most striking difference between the two species is that when $C$. vulgaris migrates*

* Meredith (1952) reports that migration does not take place in the population in Liverpool Bay. 
inshore C. allmani migrates offshore and vice versa. In the case of $C$. vulgaris, Havinga (1929, 1930), Broekema (I94I) and others have shown that salinity, temperature and breeding are significant factors in this migration. While there are differences in temperature and salinity between the deep water at $20 \mathrm{fm}$. and that at $50 \mathrm{fm}$. off the Northumberland coast, in comparison with those experienced by $C$. vulgaris these are not very great. Migration of $C$. allmani occurs at temperature maxima and minima and it tends to keep the animal in stable salinity conditions, but the breeding season is not restricted to either the offshore or inshore phase. The differences in the salinity and temperature ranges of inshore and offshore water are so small that it is difficult to visualize what is gained by migration. In the case of $C$. vulgaris rich feeding inshore and stable conditions for breeding offshore seem to be significant. As far as can be seen neither of these conditions apply in the case of C. allmani. All this would suggest is that migration in the case of C. allmani in Northumberland waters is a relict, possibly inherent, of a movement that was of importance in the past. In fact, it may be that where temperature and salinity conditions are more variable-say in the Kattegat-migration may still be important to C. allmani.

TABLE 8. TOTAL NUMBERS OF CRANGON ALLMANI TAKEN IN EACH HAUL OF 20 MIN DURATION AT STATIONS 1, 2 AND 3

St. I

I8 Nov. 1954

25 Jan. 1955

15 Feb. 1955

3I Mar. 1955

29 Apr. 1955

I6 May 1955

30 Aug. 1955

5 Oct. 1955

28 Mar. 1956

I9 Apr. 1956
St. 2

\begin{tabular}{|c|c|c|c|c|}
\hline 329 & 4 Aug. I956 & 一 & 6 Nov. I958 & $30^{\star}$ \\
\hline 852 & 5 Sept. I956 & - & I9 Mar. I959 & $32 I$ \\
\hline 314 & 30 Jan. I957 & 302 & 23 Apr. I959 & 129 \\
\hline 803 & 3I Jan. I957 & 276 & 28 May I959 & $8 \mathrm{I}$ \\
\hline 5 & I Mar. I957 & 28 & I8 June I959 & 5 \\
\hline 43 & $28 \mathrm{Mar}$. I957 & I72 & 29 June I959 & I6 \\
\hline - & 23 July I957 & - & 3 July I959 & I4 \\
\hline IO & 26 Sept. I942 & 42 & 9 July I959 & II \\
\hline I4 & 24 Oct. I957 & 36 & 4 Aug. I959 & I \\
\hline 4 & 23 Jan. I958 & I59 & I Sept. I959 & - \\
\hline & 30 Jan. I958 & I93 & I I Sept. I959 & - \\
\hline & 2I Feb. I958 & I53 & 25 Sept. I959 & - \\
\hline & 6 Mar. I958 & 54 & I3 Oct. I959 & I4 \\
\hline & 25 Aug. I958 & $4^{\star}$ & Io Nov. I959 & 94 \\
\hline
\end{tabular}

\section{SUMMARY}

St. 3

Io July 1956

I2 Sept. I956

I8 Oct. 1956

7 Dec. 1956

7 Mar. I957

4 Apr. 1957

I6 Apr. 1957

7 June 1957

2 July I957

I4 July I957

I7 July I957

30 Aug. 1957

Io Apr. I958

22 Sept. 1958

26 May 1959

I July I 959

II Aug. I959

8 Sept. 1959

24 Sept. 1959

-41
77
138
182
23
53
-
9
199
3
11
1
37
182
224
322
487
118

Since November I954 the population of C. allmani off the Northumberland coast has been sampled at number of stations.

The collections show that there is a prolonged breeding season from late December to early July. Most females produce at least two broods during each season. The time of development of the eggs of the second brood is half that of the first. Egg numbers vary from 400 to 7000 according to the size of the female and have a diameter of $390 \mu$ throughout the season. 
Growth rates and age are difficult to determine, but it is probable that C. allmani lives for $3-3 \frac{1}{2}$ years with a few females living at least one further year. Males are slightly smaller than the females.

Evidence for migration is discussed. There is an inshore movement in October and an offshore movement in April which appears to be related to temperature.

Examination of the stomach contents shows that $C$. allmani feeds predominantly on Nephthys and a variety of small crustacea. There is little difference in diet between inshore and offshore populations.

Details of the external morphology and development of secondary sexual characters are given.

Comparison is made with the life history of the closely related $C$. vulgaris.

\section{REFERENCES}

Allen, J. A., 1959. On the biology of Pandalus borealis Krøyer, with reference to a population off the Northumberland coast. F. mar. biol. Ass. U.K., Vol. 38, pp. $189-220$.

BJÖRCK, W., I913. Biologisch-Faunistische Untersuchungen aus dem Öresund, I. Pantopoda, Mysidacea und Decapoda. Acta Univ. lund., N.F., Adv. 2, Bd. 9, No. 17, 39pp.

BossaNYI, J., 1957. A preliminary survey of the small natant fauna in the vicinity of the sea floor off Blyth, Northumberland. F. Anim. Ecol., Vol. 26, pp. 353-68.

BRoekema, M. M. M., I94I. Seasonal movements and the osmotic behaviour of the shrimp Crangon crangon L. Acad. Thesis, Groningen. I00 pp.

Doflein, F., I900. Die decapoden Krebse der arktischen Meere. Fauna arct., fena, Bd. I, pp. 313-62.

Havinga, B., 1929. Krebse und Weichtiere. Handb. Seefisch. Nordeurop., Bd. 3, pp. $53-87$.

— 1930. Der Granat (C. vulgaris Fabr.) in den Holländischen Gewässern. F. Cons. int. Explor. Mer, Vol. 5, pp. 57-87.

Høglund, H., I943. On the biology and larval development of Leander squilla (L) forma typica de Man. Svenska hydrogr.-biol. Komm. Skr., N.S. Biologi, Bd. 2, No. 6, 44 pp.

IsRAEL, H. R., 1936. A contribution toward the life histories of two California shrimps, Crago franciscorum (Stimpson) and Crago nigricauda (Stimpson). Fish Bull., Sacramento, No. 46, 28 pp.

JoNES, R., I 954 . The food of the Whiting, and a comparison with that of the Haddock. Mar. Res. Scot., I954, No. 2, 34 pp.

JoRgEnSEN, O. M., I923. Plankton Investigations, I92I-22. III. Marine plankton (4) Crustacea. Rep. Dove mar. Lab., N.S., Vol. 12, pp. I12-33.

Kemp, S., I9I0. The Decapoda Natantia of the coasts of Ireland. Sci. Invest. Fish. Br. Ire., I908, No. I, $190 \mathrm{pp}$.

KINAHAN, J. R., I857. On a Crangon new to science, with notices of other nondescript Crustacea, and other observations on the distribution of the Crustacea Podophthalmia of the Eastern, or Dublin Marine, district of Ireland. Nat. Hist. Rev., Vol. 4, pp. 80-87.

1861. On the Britannic species of Crangon and Galathea; with some remark on the homologies of these groups. Trans. R. Irish. Acad., Vol. 24, pp. 45-II3. 
Lebour, M. V., I93I. The larvae of the Plymouth Caridea. I. The larvae of the Crangonidae. II. The larvae of the Hippolytidae. Proc. zool. Soc. Lond., I93I, pp. I-9.

Lloyd, A. J. \& Yonge, C. M., 1947. The biology of Crangon vulgaris L. in the Bristol Channel and Severn Estuary. F. mar. biol. Ass. U.K., Vol. 26, pp. 626-61.

MEREDITH, S. S., I952. A study of Crangon vulgaris in the Liverpool Bay area. Proc. Lpool biol. Soc., Vol. 58, pp. 75-I09.

Nouvel, H. \& Nouves, L., 1937. Recherches sur l'accouplement et la ponte chez les Crustacés Decapodes Natantia. Bull. Soc. zool. Fr., T. 62, pp. 208-21.

Ortmann, A., I891. Die Dekapoden-Krebse des Strasburger Museums. II. Zool. $F b$., Abt. Syst., Bd, 5, pp. 693-750.

Ritchie, A., I937. The food and feeding habits of the haddock in Scottish waters. Sci. Invest., Fish. Bd. Scot., 1937, No. 2, 94 pp.

SARS, G. O., I890. Bidrag til kundsskaben om Decapodernes Forvandluge. III. Fam. Crangonidae. Arch. Math. Natur., Bd. 14, pp. 132-95.

Thorsen, G., 1946. Reproduction and larval development of Danish marine bottom invertebrates, with special reference to the planktonic larvae in the Sound (Øresund). Medd. Komm. Havundersog., Kbh., Ser. Plankton, Bd. 4, No. I, $523 \mathrm{pp}$.

TopD, R. A., 1907. Second report on the food of fishes (North Sea 1904-1905). Rep. N. Sea Fish. Invest. Comm., No. 2 (Southern Area), Pt. I, pp. 49-163.

Wollebaek, A., I908. Remarks on decapod crustaceans of the North Atlantic and the Norwegian fjords. I and II. Bergens Mus. Aarb., No. 12, 74 pp.

Yonge, C. M., 1955. Egg attachment in Crangon vulgaris and other Caridea. Proc. roy. Soc. Edinb., B, Vol. 65, pp. 369-400. 